that the readership is meant to include both library science students and practicing librarians.

Some 100 library school faculty and "several reference librarians" were polled for their comments in the preparation of the second edition. As a result of these consultations, one major revision has been the elimination of the "trends" chapters of the first edition. Also, the rather lengthy listing of LC subject headings in the earlier edition for each humanities area is now reduced to one: philosophy. (Given that library science students and librarians alike have easy access to LC subject heading lists, it seems superfluous to fill more than four pages of text reproducing the many headings and subheadings of even one subject.)

The introduction serves as an informative, yet succinct, bibliographic essay. As in the first edition, the "humanities" include: philosophy, religion, visual arts, performing arts, and language and literature. Special concerns and problems of the humanities scholar are underscored, notably "the peculiarly personal and individualistic nature of humanistic research," which mandates that the humanities scholar cannot delegate bibliographic searching to others.

Following a chapter on "General Reference and Selection Aids in the Humanities," there are major sections treating each of the areas covered. Each subject area is then divided into distinct chapters on accessing information (an introductory bibliographic essay to the subject), and principal information sources (annotated entries, chosen for selection or reference value, in each subject area).

The final chapter, "The Computer and the Humanities," also revised, provides an updated discussion of research trends and electronic data bases in the humanities and points to another perennial problem of the humanities researcher: the "occasional incompatibility between scholarly needs and available computer-based information sources." The author-title and subject indexes are complete, well organized, and essential for ready reference purposes.

From the standpoint of the practicing librarian, surely the 1,200 annotated entries constitute the heart of the work. Many of the entries of the first edition that have been eclipsed or surpassed are subsumed into the annotations of the newer entries. The annotations tend to be chiefly descriptive, with evaluative comments in many cases limted to "a first choice," "vital," "useful," "essential." The length of annotated comment apparently bears little relationship to the judged value of an entry. For example, The New Cambridge Bibliography of English Literature is deemed "of fundamental importance," yet rates but a short paragraph, while Cabeen's Critical Bibliography of French Literature ("of prime importance") rates almost an entire page of annotation. One item that could well have been included with the numerous checklists of literary criticism is Kearney \& Fitzgerald, The Continental Novel: A Checklist of Criticism in English, 19001966.

This second edition of The Humanities is especially welcome to reference librarians in academic (and public) libraries as a selection and reference aid. As a classroom text in library science, the usefulness and application seem less clear.-Charles E. Perry, North Texas State University, Denton.

\section{The Role of the Humanities in the Public}

Library. Edited by Robert N. Broadus with the assistance of Brian Nielsen. Proceedings of a conference sponsored by the School of Library Science, University of North Carolina at Chapel Hill, March 5-7, 1978. Chicago: American Library Assn., 1979. 213p. \$20. LC 79-24117. ISBN 0-8389-0297-9.

Although the purpose of this conference was to "analyze the problems faced by the public library as it seeks to promote the humanities to the adult non student and suggest creative ideas which public libraries might use to this end" (p.v-vi), the discoveries presented can be used readily by academic libraries in their charge to bring students to a humanistic approach in their daily lives. There is value in searching through the papers from this conference, if only to check on one's collection-building program.

We all can agree with Dan Lacy on the need for serious books on popular topics for the general public, "the thoughtful community at large." There are numerous ways 
in which this public can be served: (1) Although some think of continuing education as the proper field for public libraries, many colleges and universities also present continuing education courses. (2) Television can spark interest in many cultural matters and offers the public an opportunity to study a variety of issues. (3) As high schools develop programs in the humanities, such efforts might spill over into the academic arena. (4) Local history is frequently the province of the public library, but many academic libraries build such collections as well for research purposes. (5) Surely academic libraries can cooperate with public libraries in continuing support of programs in the humanities that treat the enduring questions of human life.

The academic library can encourage the humanistic attitude of its students by being willing to buy such materials, even if they are not popular-buying more for quality than for demand. Sometimes public libraries cannot afford this so-called luxury (p.8-10).

Academic librarians think of the library as an information place for students, and rightly so; yet we cannot forget our obligation to be a cultural center as well (p.23). Furthermore, a greater cooperation between public and academic libraries helps to unearth those many human resources that can be found in the geographical area (p.25).

Not only the presenters but also the discussants referred to the academic library and its role in exposing students to the humanities as part of the library's total role in the academic setting. Thus the minds of students can be enhanced for their entire lives. In other words, a lessening of required courses to prepare one to earn a living in a certain field allows the student to aim for some humanistic goals also (e.g., p.66).

In addition, community colleges, universities, and four-year colleges, insofar as they aim to fulfill their continuing education mission, should be careful not to get bogged down in credit hours solely. Opportunities should exist to advance oneself humanistically without taking courses for credit, and the charge should be less, since record keeping is minimal (p.94).

Some of the ideas developed by museum director E. L. Chalmers might well be studied by academic librarians and adapted to their particular situation. Librarians are interested in developing monetary resources, to say nothing about involving the community in the needs of libraries (p.139 ff.).

Many might wish to emphasize an idea tried in some libraries already and currently being tested by banks-the personal librarian and the personal banker. The introduction of the personal librarian, especially for the heavy user of materials, may prove a useful option (p.158).

Unlike the television station that can offer only one thing at a time, the library can offer all users something to suit their individual needs or interests-the riches of humanistic scholars (p.210).-Jovian P. Lang, OFM, St. John's University, Jamaica, New York.

\section{College and University Archives: Selected}

Readings. Chicago: Society of American Archivists, 1979. 234p. $\$ 11$; $\$ 8$ for SAA members. LC 79-19917. ISBN 0-93182816-3.

College and University Archives: Selected Readings contains seventeen articles and six appendixes selected primarily from the published literature in the field by a subcommittee of the Society of American Archivists Committee on College and University Archives. These readings are intended to provide assistance to novices in an area of archival administration now comprising the largest single employment category in the profession. Though most useful to practitioners, the readings also provide valuable information to administrators concerned with the costs and benefits of an archival program.

Reading lists for any course in archival theory and practice should include College and University Archives. Many of the articles relate to more than one topic and cannot be neatly categorized, but a student might profitably approach this compilation by reading first Ernst Posner's historical essay, "The College and University Archives in the United States," and Ian E. Wilson's parallel treatment, "Canadian University Archives."

Overviews of how to set up and adminis- 